International Journal of Social Sciences and Humanities
Available online at http://sciencescholar.us/journal/index.php/ijssh
Vol. 1 No. 2, August 2017, pages: $65 \sim 74$
e-ISSN: 2550-7001, p-ISSN: 2550-701X
http://dx.doi.org/10.21744/ijssh.v1i2.44

\title{
The Marketing Mix Affect on the Consumer Buying Decision (Case Study of Sausage Products at PT. Aroma Denpasar)
}

\author{
(C) CrossMark \\ I Made Jaminyasa a ; I Made Pulawan ${ }^{\text {b; }}$ A.A. Media Martadiani c; \\ I Made Suniastha Amerta ${ }^{\mathrm{d}}$ \\ Article history: Received 2 February 2017 ; Accepted in revised form 5 July 2017 ; Approved 21 July 2017 ; \\ Available online 30 August 2017
}

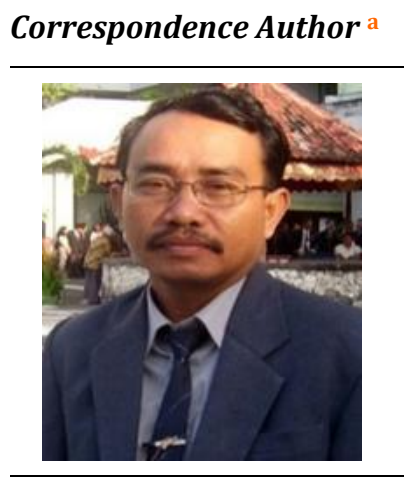

Keywords

Buying Decision;

Consumer;

Marketing mix affect;

PT. Aroma Denpasar;

Sausage products;

\section{Abstract}

The more intense competition within the similar business as well as happened in the business of making sausages, especially in Denpasar city. PT. Aroma was one of the companies in Denpasar that produces sausages, corned beef, and nuggets. In an effort to attract consumers to buy sausages, companies pay attention to product quality, price, and promotion. The attitude of each consumer varies before buying and in buying products. Consumer considerations in buying the products that need to be considered by marketers, so that products that are marketed can be accepted and would be bought by the consumers. The linear regression line equation: $\mathrm{Y}=0.1920+0.2145 \mathrm{X} 1+0.2592 \mathrm{X} 2+0.3828 \mathrm{X} 3$ explains that there was a simultaneous positive influence between product quality, price, and promotion on the buying decision of sausage. The result of $t$-test of regression coefficient obtained t1count was 3,3628, t2-count was 3,9879 and t3-count was 6,2641 bigger than t-table equal to 1,980 was in rejection region Ho, hence Ho rejected or Hi accepted. It meant it was true, that there was a positive influence simultaneously between the marketing mix and the consumer buying decision.

\footnotetext{
a Senior Lecturer at the Management Studies Program, Faculty of Economics, Warmadewa University, Denpasar (madejaminyasa@gmail.com)

b Senior Lecturer at the Management Studies Program, Faculty of Economics, Warmadewa University, Denpasar (pulawanimade@gmail.com)

c Senior Lecturer at the Management Studies Program, Faculty of Economics, Warmadewa University, Denpasar (mediamartadiani@yahoo.com)

d Senior Lecturer at the Management Studies Program, Faculty of Economics, Warmadewa University, Denpasar (jrokadek@yahoo.co.id)
} 
e-ISSN : 2550-7001, p-ISSN : 2550-701X@ Copyright 2017. The Author. SS Journals Published by Universidad Técnica de Manabí.

This is an open-access article under the CC BY-SA 4.0 license

(https://creativecommons.org/licenses/by-sa/4.0/)

All rights reserved.

\section{Contents}

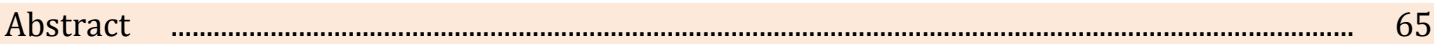

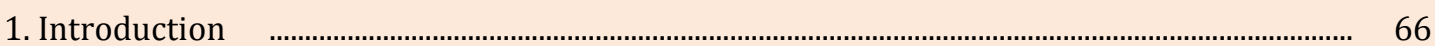

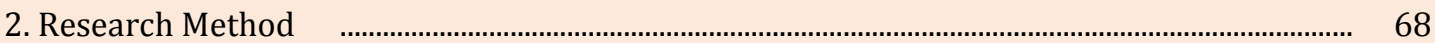

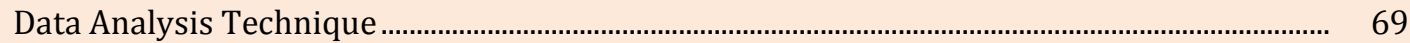

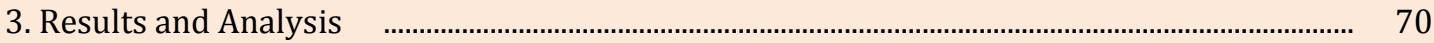

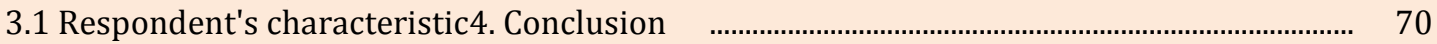

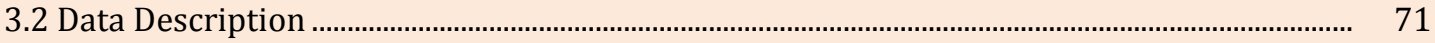

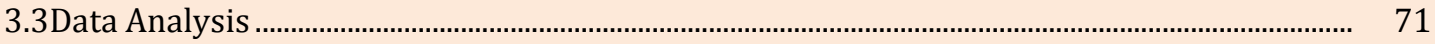

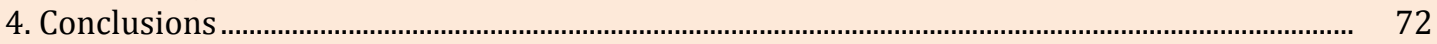

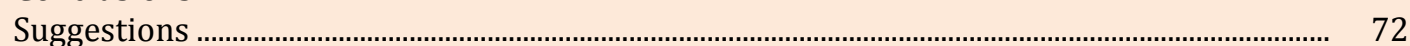

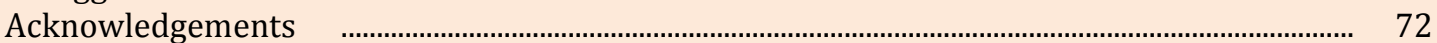

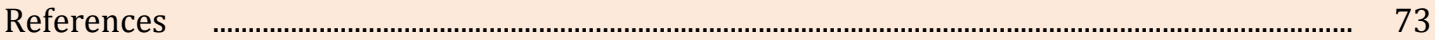

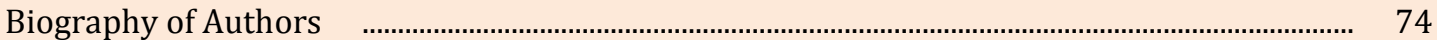

\section{Introduction}

One characteristic of globalization is that the rapidly growing industry, rapidly influenced by technological advances, and rapid human mobility. This resulted in every effort made can progress rapidly. The recent global trends in both the socio-political, economic and security fields directly impact on almost all fields. The competition among industries can not be avoided. Only those who managed to reap the wisdom of a global trend will be able to survive. This condition clearly indicates the tight of competition in the industry in seizing consumers to buy their products.

The consumers' behavior is one of the factors that can affect the consumer consideration. Their attitude can lead to a tendency to make an offer to the product produced by the company (Kotler, 2005: 16). Through an understanding of consumer attitude, the company can understand the needs of consumers and the existence of products to be marketed so as to provide satisfaction to consumers.

Understanding buyer behavior of target markets is an important task in the marketing management based on the marketing concepts (Kotler, 2005: 16). Based on these opinions, it can be seen that the key to achieving marketing objectives through the fulfillment of needs and desires of consumers in the target market must be supported by understanding consumer's attitude in the target market itself. Consumers' attitude in making the decision to buy becomes very important because the target market is driven by the strengths that exist in the consumer, which is an external factor of an industry. The ability of an industry to introduce its products through media campaigns and information.

In this free business competition, the requirement for a company to succeed in the competition is to achieve the created goal and retain customers. In order to achieve these objectives, each company must be able to produce and deliver goods and services that consumers want in accordance with their needs and desires.

The entrepreneurs as producers are not only tasked to create a product or service alone but also with the ability to know the needs of consumers of a product or service. Entrepreneurs are vying to look for factors that influence consumers in choosing a product and devising appropriate marketing strategies so that it can dominate the existing market. The success of the company to establish customer relationships, so that it can survive in the 
long term and can maintain customer relationships on an ongoing basis is a competitive advantage for the company.

Proper pricing of a good or service by the firm will provide the most by creating some net income and profits. If the company focuses on price competition, it will face two alternatives, namely to make price changes and react to changes in competitors' prices. If the price is set too high will result in less profit. In this case, the buyer will decrease and the sales value will decrease (Assauri, 2007: 232).

Sausage is a food that has been familiar with the life of Indonesian society because it tastes good. This food is made from meat or minced fish then mashed, seasoned, put into a symmetrical sponge selonsong, whether made from animal gut or casing. Sausage is one of the processed meat or fish products that are very popular among Indonesian people since the 1980s. The term sausage comes from the Latin, which is salsus, which means salt. This refers to the meaning of cut or crushed meat preserved by salting.

Types of sausages sold to consumers at PT. Aroma in Denpasar consists of pork sausage, beef sausage, and chicken sausage. In connection with the business development, in table 1 below, can be seen the value of sausage sales at PT. Aroma in Denpasar from 2012 until 2016.

Table 1

Sales Value of Each Type of Sausage at PT. Aroma in Denpasar, Year 2012-2016

\begin{tabular}{|c|c|c|c|c|c|}
\hline \multirow[b]{2}{*}{ Years } & \multicolumn{3}{|c|}{ Sales Value of Each Type of Sausage } & \multirow[b]{2}{*}{$\begin{array}{l}\text { Total Sales Value } \\
\text { (Rp) }\end{array}$} & \multirow[b]{2}{*}{$\begin{array}{l}\text { Prosentase } \\
\text { Perubahan }\end{array}$} \\
\hline & $\begin{array}{c}\text { Pork Sausage } \\
\text { (Rp) }\end{array}$ & $\begin{array}{c}\text { Beef Sausage } \\
\text { (Rp) }\end{array}$ & $\begin{array}{c}\text { Chicken Sausage } \\
\text { (Rp) }\end{array}$ & & \\
\hline 2012 & 120.422 .522 .200 & 305.116 .245 .400 & 425.165 .540 .000 & 850.704 .307 .600 & - \\
\hline 2013 & 170.475 .748 .300 & 285.325.337.000 & 325.450 & & \\
\hline 2014 & 158.615 .250 .400 & 271.687.234.200 & 468.762 .568 .400 & & \\
\hline 2015 & 182.077.672.700 & 324.908 .225 .500 & 522.784 .388 .200 & 1.029.770.286.400 & \\
\hline 2016 & 131.239 .887 .500 & 290.876 .459 .200 & 419.224 .324 .500 & 841.340 .671 .200 & $(18,30)$ \\
\hline Total & 762.831 .081 .100 & 1.477 .913 .501 .300 & 2.161.387.010.600 & 4.402.131.593.000 & 3,16 \\
\hline Average & 152.566.216.220 & 295.582 .700 .260 & 432.277 .402 .120 & 880.426 .318 .600 & 0,79 \\
\hline
\end{tabular}

Companies are required to increase efforts made related to product quality to attract consumers to buy sausages on offer. Quality can be elaborated more complexly as an advantage, so the perceived quality can be defined as a consumer statement about the overall superiority of the sausage. From the initial research, in general, the quality of the resulting product is quite good but still encountered a product with a less good packaging that hygiene products are not guaranteed.

The price of sausage set by PT. Aroma in Denpasar in accordance with market conditions. The basic price set is Rp.2.500, - / pcs for pork sausage, Rp.2.200 / pcs for beef sausage and Rp.1.800, - / pcs for chicken sausage. Price changes can occur that can increase or decrease in accordance with company policy by looking at the conditions of competition faced by companies with similar businesses. PT. Aroma in Denpasar provides discounts to consumers for large quantities of product buying. Price discounts are given in the range of $2 \%-5 \%$ if the buying of the product is at least 100 packs and if more than 200 pack then the discounted price is given at $10 \%-20 \%$.

Promotion activities at PT. Aroma in Denpasar consists of advertising, sales promotion, and personal selling. Advertising is a company active in promoting its products by printing brochures. The brochures used can be described as printed publications using slippery paper folded containing the company's name, address, telephone, fax, e-mail and website address. Trough the brochures, It is also explained some potential of the product, such as product type and product price. These brochures are distributed in mini markets and supermarkets.

Jaminyasa, I. M., Pulawan, I. M., Martadiani, A. M., \& Amerta, I. M. S. (2017). The marketing mix affect on the consumer buying decision (case study of sausage products at PT. Aroma Denpasar). International Journal of Social Sciences and Humanities, 1(2), 65-74. https://doi.org/10.29332/ijssh.v1n2.44 
Sales promotion is a company's activity in promoting its products by way of giving business cards and giving price discounts to introduce and offer products sold. Personal selling is done by means of individual persuasive communication to prospective consumers by marketing personnel by phone and goes directly to the outlets that exist to raise cooperation by explaining the products owned. The demand for globalization requires that direct marketing is a promotional undertaking in offering its services to off-site consumers through direct mail, telemarketing and internet use. This has not been well implemented, only limited to company information.

The attitude of each consumer is different in making a buying and before making a buying, consumers generally first try to determine why, what, where and how to buy a product. Consumer considerations in buying products that should be considered by marketers, so that the marketed product can be accepted and would be buying from the consumer.

From the description above, the problem can be formulated "How the relationship and influence partially or simultaneously between the marketing mix (product quality, price, and promotion) with the decision to buy sausage at PT. Aroma.

\section{Research Method}

This research was conducted at PT. Aroma on Jalan By Pass Ngurah Rai No.555X Denpasar Budget in 2016, with the object of research, is product quality, price and promotion and buying decision sausage. The main purpose of this study is to analyze simultaneously or partially / individually between marketing mix (decision of sausage product at PT Aroma in Denpasar.

The consumer buying decision process passes through five stages in the process of buying a product. These five stages do not apply to buying with little clarity because this stage is full of appetites that arise when a consumer applies new with high keywords. Five stages of the consumer buying process like figure 1.

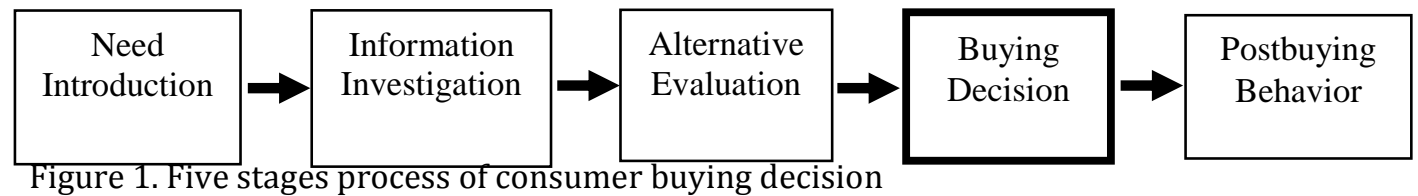

Source: Kotler (2005: 224).

The population in this study is the number of consumers who buy sausage at PT. Aroma in Denpasar in December of 2016. They were 2,527 consumers. The sample in this study was determined by using the Slovin formula (Husein Umar, 2005: 108), namely:

$$
\mathrm{n}=\frac{\mathrm{N}}{1+\mathrm{Ne}^{2}}
$$

The results of these calculations known the number of samples of 97 people as consumers. Determination of samples using accidental sampling technique means that consumers who used as samples are consumers who have completed a transaction at PT. Aroma Denpasar as the location of the research.

\section{Data Analysis Technique}

\section{a. Quantitative Analysis}

Quantitative analysis is done after the data collected. The data source of this research is the withdrawal of primary data on product quality variables, price, promotion and 
product buying decision by using questionnaire. The data is quantified by giving a score on each respondent's answer.

Likert scale is used to measure attitudes, opinions, and perceptions of a person or group of people about social phenomena (Sugiyono, 2008: 132). Each questionnaire answers product quality, price, promotion and product buying decisions have a weight or score with Likert scale as follows:

a. Answer a. very good, got a score of 5

b. Answer b. well, got a score of 4

c. Answers c. good enough got a score of 3

d. Answers d. not good, got score 2

e. Answers e. very poor, got a score of 1 .

The data obtained from the results of research after tabulation of data, then further analyzed by statistical analysis as follows:

The data obtained from the results of research after tabulation of data, then further analyzed by statistical analysis as follows.

a. Individual Correlation Analysis

This analysis is used to determine the degree of individual relationships between product quality, price, and promotion with the sausage buying decision.

The formula (Sugiyono, 2008: 248):

The coefficient of correlation between product quality (X1) with the sausage buying decision $(\mathrm{Y})$ :

$$
\mathrm{R}_{\mathrm{y} 1}=\frac{\sum \mathrm{x}_{1} \mathrm{y}}{\left(\sum \mathrm{x}_{1}^{2}\right)\left(\sum \mathrm{y}^{2}\right)}
$$

The coefficient of correlation between price (X2) with the sausage buying decision (Y):

$$
\mathrm{R}_{\mathrm{y} 2}=\frac{\sum \mathrm{x}_{2} \mathrm{y}}{\left(\sum \mathrm{x}_{2}{ }^{2}\right)\left(\sum \mathrm{y}^{2}\right)}
$$

The coefficient of correlation between promotion (X3) with the sausage buying decision $(\mathrm{Y})$ :

$$
\mathrm{R}_{\mathrm{y} 3}=\frac{\sum \mathrm{x}_{3} \mathrm{y}}{\left(\sum \mathrm{x}_{3}{ }^{2}\right)\left(\sum \mathrm{y}^{2}\right)}
$$

b. Multiple Correlation Analysis

This analysis is used to measure the degree of relationship simultaneously between product quality, price, and promotion with the sausage buying decision.

The formula (Riduwan and Sunarto, 2007: 110):

$$
\operatorname{Ry}_{(1,2,3)}=\sqrt{\frac{\mathrm{b}_{1} \sum \mathrm{x}_{1} \mathrm{y}+\mathrm{b}_{2} \sum \mathrm{x}_{2} \mathrm{y}+\mathrm{b}_{3} \sum \mathrm{x}_{3} \mathrm{y}}{\sum \mathrm{y}^{2}}}
$$

Jaminyasa, I. M., Pulawan, I. M., Martadiani, A. M., \& Amerta, I. M. S. (2017). The marketing mix affect on the consumer buying decision (case study of sausage products at PT. Aroma Denpasar). International Journal of Social Sciences and Humanities, 1(2), 65-74. https://doi.org/10.29332/ijssh.v1n2.44 
c. F-test

F-test is used to test the significance of multiple correlation coefficients (R), so as to know the relationship simultaneously between product quality, price, and promotion with the sausage buying decision. It has factually happened significantly or it has happened accidentally.

Formuls (Sugiyono, $2008: 257$ ) :

$$
\mathrm{F}=\frac{\mathrm{R}^{2} / \mathrm{k}}{\left(1-\mathrm{R}^{2}\right) /(\mathrm{n}-\mathrm{k}-1)}
$$

\section{Results and Analysis}

Based on the research objectives, in this session, it will be presented the relationship analysis either individually and simultaneously among the product quality, price, and promotion with the sausage buying decision. In addition, it will be also presented the affect analysis simultaneously and individually among product quality, price, and promotion to the sausage buying decision at PT. Aroma in Denpasar.

\subsection{Respondent's characteristic}

The number of samples of the study was 97 consumers. The respondents were used as samples met at the research location at PT. Aroma in Denpasar were the consumers who have completed a transaction that happened to meet in. The identity of respondents in this study with various characteristics can be seen in table 2 below.

Table 2

Identity of Respondents with Various Characteristics, At PT. Aroma in Denpasar

\begin{tabular}{lllrr}
\hline No & \multicolumn{1}{c}{ Characteristic } & \multicolumn{1}{c}{ Selection } & $\begin{array}{c}\text { Frequency } \\
\text { (Person) }\end{array}$ & Percentage(\%) \\
\hline 1. & Age & a. $<20$ years & 9 & 9,28 \\
& & b. $21-30$ years & 20 & 20,62 \\
& & c. $31-40$ years & 42 & 43,30 \\
& & d. $>40$ years & 26 & 26,80 \\
2. Amount & Gender & a. Male & 97 & 100,00 \\
& & b. Female & 24 & 24,74 \\
& Amount & & 73 & 75,26 \\
3. & Education & a. SLTP & 97 & 100,00 \\
& & a. SLTA & 12 & 12,37 \\
& & b. S1 & 56 & 57,73 \\
& & c. S & 23 & 23,71 \\
& Amount & & 6 & 6,19 \\
4. Frequency of Buying & a. Often & 97 & 100,00 \\
& & b. Rarely & 69 & 71,13 \\
& Amount & & 28 & 28,87 \\
\end{tabular}

\subsection{Data Description}

The data obtained were described descriptively to get a complete picture of the research data. The research was conducted by using a questionnaire to be answered by 97 consumers of PT. Aroma in Denpasar as the respondents of the research. Each of the product quality and price variables consists of four statements, while the promotion and buying decision of each sausage consists of three statements. Each questionnaire answer has a weight or score: 
1. Answer a. SB (very good), got a score of 5

2. Answers b. B (good), got a score of 4

3. Answers c. CB (good enough), got a score of 3

4. Answers d. KB (less good), got a score of 2

5. Answers e. LCS (very bad), got a score of 1 .

\subsection{Data Analysis}

Based on the number of scores of each variable, the next stage was completing the statistical calculations with a computer using statistical program packages for social sciences. The SPSS (Statistical Product and Service Solution) 16.0 for Windows was used.

After analyzing the data, further discussion was also done to determine the broader meaning of the analysis results. The partial/individual correlation coefficient obtained. (1) ry1 was 0.6264 indicated there was a positive and high correlation individually between the quality of the product and the buying decision of the sausage; (2) ry2 was 0.7154 indicateD there was a positive and high correlation individually between the price with the buying decision of sausage and ry3 is 0.6305 means there is a positive and high correlation individually between promotion with the decision of buying sausage. Positive relationship explains the unidirectional relationship that if the quality of product, price, and promotion individually improved then will be followed by increasing decision of buying sausage. The significance test of individual correlation coefficient obtained t1-count is 7,8327, t2-count was 9,9796 and t3-count was 7,9171 bigger than t-table equal to 1,658 is in rejection region Ho then Ho rejected or Hi accepted, it was true there was a positive and real (significant) relationship individually between product quality, price and promotion with the buying decision of sausage and not obtained by chance.

The coefficient of multiple correlations is 0.8241 means there was a very positive and very high relationship simultaneously between product quality, price, and promotion with the decision of buying sausage. Positive relationship explains the direct relationship was that if simultaneously the quality of products, prices, and promotions improved, it would be followed by increasing the sausage buying decisions. The significance test of multiple correlation coefficients obtained F-count was 65,6209 bigger than F-table equal to 2,68 was in rejection region $\mathrm{Ho}$, hence Ho rejected or $\mathrm{Hi}$ accepted. It meant that it was true there was a positive and significant relation (significant) simultaneously between product quality, price, and promotion with the buying decision of the sausage and it was not obtained by chance. The coefficient of determination was $67,92 \%$ meant variation of the simultaneous relationship between product quality, price, and promotion with the decision of buying of sausage was equal to $67,92 \%$ while the rest $32,08 \%$ was determined by another variable outside product quality, price, and promotion which was not discussed in this research.

The equation of multiple linear regression lines: $\mathrm{Y}=0,1920+0,2145 \mathrm{X} 1+0,2592 \mathrm{X} 2+$ $0,3828 \mathrm{X} 3$ explained that there was a positive influence simultaneously on product quality, price and promotion to decision of buying of sausage or in other words, the increasing of the sausage buying decisions were influenced simultaneously by improving product quality, price, and promotion. The significance test of regression coefficient obtained t1-count was 3.3628, $\mathrm{t} 2$-count was 3.9879 and $\mathrm{t} 3$-count is 6,2641 bigger than $\mathrm{t}$-table equal to 1,980 were in rejection region $\mathrm{Ho}$, Ho was rejected or $\mathrm{Hi}$ accepted, it was true that there was a positive and significant effect (individual) between the quality of the product, the price and the promotion of the buying decision of the sausage and was not by chance.

The results showed that product quality, price, and promotion got a positive response from consumers in taking the decision to buy sausage at PT. Aroma in Denpasar. This was important to do, considering PT. Aroma in Denpasar as a producer was not only tasked to produce sausage products but also with the ability to know consumer needs. The success of the company to establish relationships with consumers, so that it can survive in the long term

Jaminyasa, I. M., Pulawan, I. M., Martadiani, A. M., \& Amerta, I. M. S. (2017). The marketing mix affect on the consumer buying decision (case study of sausage products at PT. Aroma Denpasar). International Journal of Social Sciences and Humanities, 1(2), 65-74. https://doi.org/10.29332/ijssh.v1n2.44 
and can maintain customer relationships within a competitive and beneficial for the company.

\section{Conclusions}

Based on the results of data analysis and discussion, some conclusions of the research results can be concluded as follows.

a. There was a positive and significant relationship partially / individually or simultaneously between product quality, price, and promotion with the decision of buying sausage at PT. Aroma in Denpasar.

b. There was a positive and significant influence simultaneously and individually between product quality, price, and promotion of the decision to buy sausage at $P T$. Aroma in Denpasar.

\section{Suggestions}

Based on the conclusions stated above, it can be suggested for the management of PT. Aroma in Denpasar, in an attempt to influence consumer behavior in making the buying of sausage, as follows.

a. Improve the quality of raw materials and auxiliary so that the sausage produced durable in addition to more product type and variety of flavors.

b. Increase the number of discounts, especially for the buying of sausages in large quantities to all consumers in accordance with product quality so that sausage prices can compete in the market.

c. Increase the promotional media used and increase the frequency of promotions made in addition to expanding the reach of promotion so that more consumers are interested in buying sausages.

\section{Acknowledgement}

The authors would like to thank and deliver a high appreciation to the Rector of Warmadewa University and the Dean of Faculty of Economics of Warmadewa University. Thanks are also referred to the Head of Management Study Program Warmadewa University for any facility that has been given to the author. The last but not least, thanks as well as extended to the informants, particularly, in PT. Aroma Denpasar. 


\section{References}

Adetunji, A. T., Adetunji, A. V., Adeleke, E. O., \& Madubuike, S. C. (2017). Deregulation: The Effect of Market-led Approach to Nigerian Universities Management. International Journal of Social Sciences and Humanities (IJSSH), 1(1), 1-8.

Astawa, I. N., Mantra, I. B. N., \& Widiastuti, I. A. M. S. (2017). Developing Communicative English Language Tests for Tourism Vocational High School Students. International Journal of Social Sciences and Humanities (IJSSH), 1(2), 58-64.

Basak, A., \& Khanna, K. (2017). A Study on the Selection Criteria of Different Hotels of Delhi NCR in Accordance to the HR Policies and Market Trends. International Journal of Social Sciences and Humanities (IJSSH), 1(1), 27-38.

Billaiya, R., Malaiya, S., \& Parihar, K. S. (2017). Impact of Socio Economic Trends on Students in Quality Education System. International Journal of Social Sciences and Humanities (IJSSH), $1(1), 16-20$.

Fandy Tjiptono, (2006), Marketing Strategy, Second Edition, Andi Publisher, Yogyakarta.

Ghosh, C. (2017). A Study on-Evaluating Marketing Strategies Adopted by Home Appliance for Economic Development in India. International Journal of Social Sciences and Humanities (IJSSH), 1(1), 9-15.

Henry Simamora, (2005), Marketing Management, Penerbit Salemba Empat, Jakarta.

http://kopisusu. wordpress.com/2006.

Husaini Usman and Purnomo Setiadi Akbar, (2009), Introduction to Statistics, Publisher Bumi Aksara, Jakarta.

Indriyo Gitosudarmo, (2006), Marketing Management, First Edition, Publisher BPFE, Yogyakarta.

M. Mursid, (2006), Marketing Management, Publisher Bumi Aksara, Jakarta.

M. Suyanto, (2007), Marketing Strategy Top Brand Indonesia, Publisher Andi, Yogyakarta.

Maba, W. (2017). Teacher's Perception on the Implementation of the Assessment Process in 2013 Curriculum. International Journal of Social Sciences and Humanities (IJSSH), 1(2), 1-9.

Marius P. Angipora, (2005), Dasar-Dasar Pemasaran, Edisi Kedua, PT. Raja Grafindo Persada, Jakarta.

Nirwana, (2006), Service Marketing Strategy, Publisher Dioma, Malang.

Philip Kotler, (2005), Marketing Management, Volume 1, Eleventh Edition, Publisher PT. Indeks Kelompok Gramedia, Jakarta.

Riduwan dan Sunarto, (2007), Introduction to Statistics For Educational, Social, Economic, and Business Research, Publisher Alfabeta, Bandung.

Sofjan Assauri, (2007), Marketing Management, Concepts, Basics and Strategies, Seventh Printing, Publisher PT. Rajagrafindo Persada, Jakarta.

Sugiyono, (2008), Business Research Methods, Publisher Alfabeta, Bandung.

Suryasa, I. W., Prayoga, I. G. P. A., \& Werdistira, I. W. A. (2017). An Analysis of Students' Motivation Toward English Learning As Second Language Among Students In Pritchard English Academy (PEACE). International Journal of Social Sciences and Humanities (IJSSH), 1(2), 43-50.

WY. Stanton, (2007), http://www.organisasi.org/arti-definisi-pengertian-pemasaran-menurutpara-ahli-ilmu-manajemen-pemasaran-marketing-dasar

Jaminyasa, I. M., Pulawan, I. M., Martadiani, A. M., \& Amerta, I. M. S. (2017). The marketing mix affect on the consumer buying decision (case study of sausage products at PT. Aroma Denpasar). 


\section{Biography of Authors}

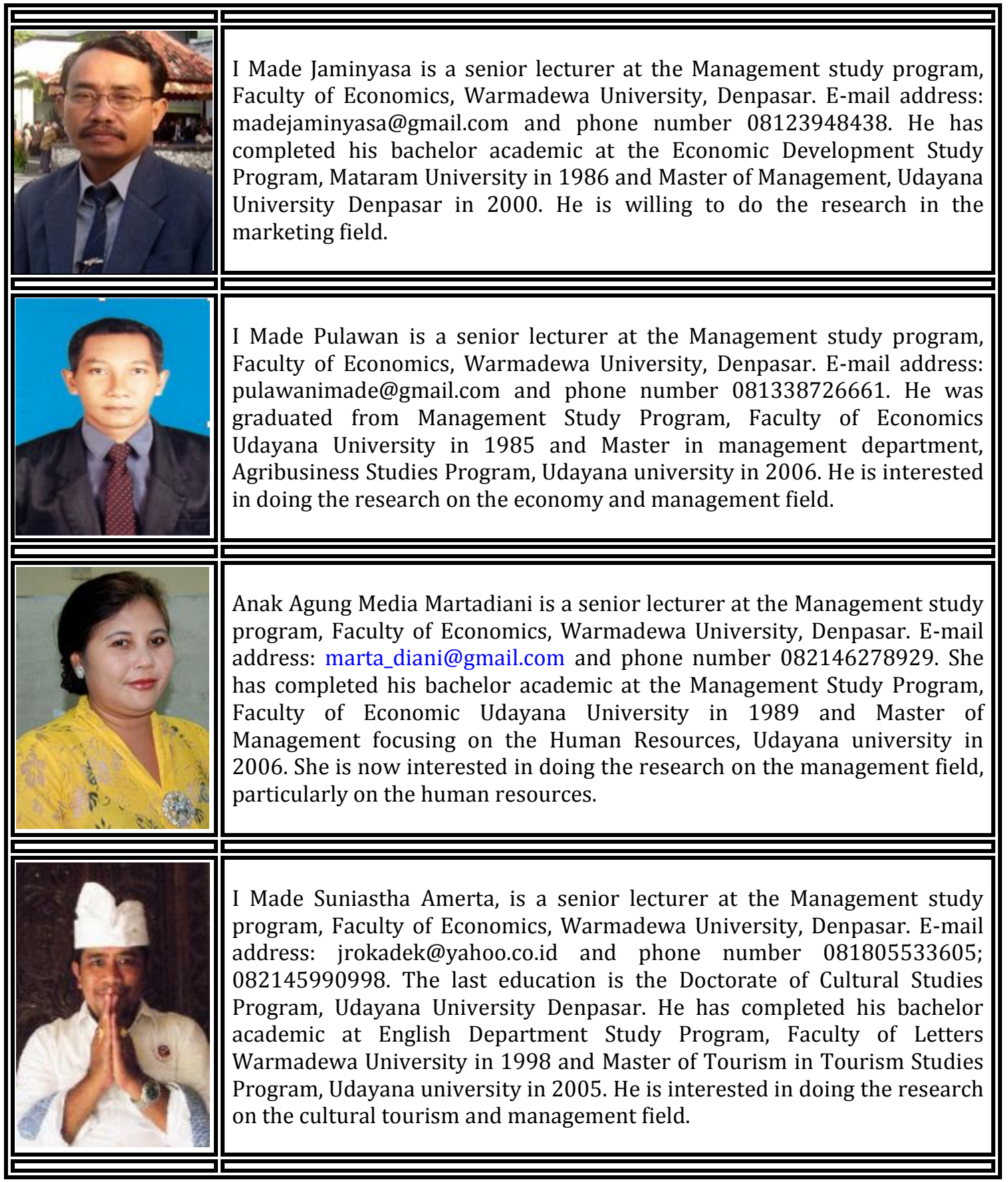

